\title{
UVODNIK
}

\section{VETERANSKE ORGANIZACIJE - ALI JIH SPLOH POTREBUJEMO?}

Ko razpravljamo o veteranih in veteranskih organizacijah, je običajno prva misel povezana s preteklostjo. Najprej pomislimo na različne vojne in njihove posledice. Na vse tiste, ki so v vojnah sodelovali in imeli srečo, da so ostali zdravi in nepoškodovani. In tudi na vse tiste, ki jim je vojna pustila različne posledice, nekaterim telesne ali čustvene, še več pa je takih, ki se spopadajo z obojimi.

Čeprav imamo danes veliko srečo in so vojne na območju Evropske unije predvsem predmet zgodovinskih razprav, smo se v uredniškem odboru Sodobnih vojaških izzivov odločili, da posvetimo tematsko številko tudi temi veteranskih organizacij in njihovi vlogi v sodobni družbi.

Vojni veterani so sestavni del slovenske, širše evropske in globalne družbe. Prepoznavamo jih glede na različne vojne in posamične oborožene konflikte. V različnih okoljih so obravnavani in organizirani zelo različno, tudi njihov vpliv na oblikovanje sodobne družbe se razlikuje. Nekateri med njimi pa nimajo ničesar, ker so bili na napačni strani. Napačna stran ni več povsod problematizirana, kot je bila nekoč, saj se je razumevanje konflikta iz preteklosti preoblikovalo v tvorno sodelovanje za prihodnost.

Vprašanje veteranskih organizacij oziroma vprašanje, ali jih sploh potrebujemo, ostaja tako retorično vprašanje, še posebno ob pojavu novih veteranskih organizacij, ki jih sestavljajo veterani različnih mednarodnih operacij in misij, tudi v državah, ki sicer drugih (vojnih) veteranov sploh nimajo.

Tematska številka, ki je pred vami, je nastala v sodelovanju z Vladimirjem Prebiličem kot gostujočim urednikom in nekaterimi udeleženci mednarodnega posveta, ki je bil v Ljubljani lansko poletje. 
Vladimir Prebilič nas uvodoma v članku z naslovom Veteranski imperativ danes seznani s temeljnimi pojmi veteranov, kdo sploh so, kaj in kakšen je veteranski imperativ in kako se kaže v sodobnih družbah, še posebej v tistih, v katerih so oborožene sile profesionalizirane, s čimer so teme, povezane z nacionalno varnostjo in vojaštvom, potisnjene na obrobje.

O obravnavi veteranov v prejšnjem stoletju v Romuniji razpravlja Carmen Sorina Rijnoveanu v članku Ponovno ovrednotenje statusa veteranov v postkomunističnih družbah - primer Romunije. Romunija se je najprej pridružila nemškemu rajhu v boju proti Sovjetski zvezi, pozneje pa prišla pod njen vpliv, kar je bilo slabo za nekatere veterane. Po letu 1990 se je situacija ponovno spremenila.

Velik izziv so po drugi svetovni vojni predstavljali veterani v Nemčiji in Franciji, ki so kljub temu, da so bili na nasprotujočih si straneh, razvili uspešno sodelovanje. O tem zanimivem pojavu piše Jörg Echternkamp v članku Od sovražnika do prijatelja? Veterani kot gonilna sila mednarodne sprave po drugi svetovni vojni.

Veterani in filantropija po veliki vojni: vloga in stališča fundacije Carnegie za mednarodni mir je naslov članka Nadine Akhund-Lange, ki se je posvetila raziskovanju organizacije, ki je bila ustanovljena po prvi svetovni vojni, predvsem z nalogo poskrbeti za vojne veterane in vojne invalide. O tem, kako uspešna je bila, lahko več preberete v njenem članku.

Valerija Bernik v članku z naslovom Veteranke druge svetovne vojne predstavlja mobilizacijo žensk v oborožene sile različnih držav, ki po oboroženih spopadih niso dobile enakega statusa veterank kot njihovi moški kolegi, ne le v formalnem, temveč tudi v družbenem smislu.

Članek z naslovom Dolga pot do uradne danske veteranske politike, 1848-2010, sta napisala Niels Bo Poulsen in Jakob Brink Rasmussen. Pišeta o danski veteranski politiki, ki je uraden dokument na tem področju dobila šele leta 2010. Veliko različnih dejavnikov je vplivalo na to, da na Danskem to področje ni bilo urejeno, najbolj zanimivi pa so tisti, ki so nedavno tega končno omogočili spremembo.

O tem, kako je urejeno področje veteranskih organizacij v Sloveniji, sta članek napisala Alojz Šteiner in Tomaž Čas. Domoljubne in veteranske organizacije primer Slovenije je naslov njunega prispevka, v katerem obravnavata številne domače veteranske organizacije in njihovo družbeno vlogo. Teh organizacij je sorazmerno veliko, imajo raznoliko programsko vsebino in so večinoma zelo aktivne.

Želimo vam veliko zanimivega branja in prijetno poletje! 